$\begin{array}{ll} & \text { Etnográfica } \\ \text { etnográfica } & \text { Revista do Centro em Rede de Investigação em }\end{array}$

Antropologia

vol. $25(2) \mid 2021$

Vol. 25 (2)

\title{
Trilhas de sangue e mel: esboço peregrino de uma cosmoecologia negra, no sul do Brasil
}

Trails of blood and honey: pilgrim draft of a black cosmos-ecology in southern Brazil

\section{Marília Floôr Kosby}

\section{(2) OpenEdition}

\section{Journals}

Edição electrónica

URL: https://journals.openedition.org/etnografica/9782

DOI: 10.4000/etnografica.9782

ISSN: 2182-2891

\section{Editora}

Centro em Rede de Investigação em Antropologia

\section{Edição impressa}

Paginação: 379-403

ISSN: 0873-6561

Refêrencia eletrónica

Marília Floôr Kosby, «Trilhas de sangue e mel: esboço peregrino de uma cosmoecologia negra, no sul do Brasil», Etnográfica [Online], vol. 25 (2) | 2021, posto online no dia 29 julho 2021, consultado o 19 janeiro 2022. URL: http://journals.openedition.org/etnografica/9782 ; DOI: https://doi.org/10.4000/ etnografica. 9782

Etnográfica is licensed under a Creative Commons Attribution-NonCommercial 4.0 International License. 


\section{Trilhas de sangue e mel: esboço peregrino de uma cosmoecologia negra no sul do Brasil}

\section{Marília Floôr Kosby}

Ao seguir cabras criadas em uma comunidade negra rural do extremo sul do Brasil até casas de religião de matriz africana na região metropolitana de Porto Alegre, Rio Grande do Sul, este artigo pretende-se uma narrativa peregrina (Ingold 2015) de perspectiva contraidentitária (Anjos 2006) das trilhas e zonas de passagem em que quilombos e terreiros criam cosmoecologias comuns. No entrelaçamento de multiplicidades concretas, percebe-se a partilha do que se pode chamar de uma cosmoecologia negra, imbricando (e implicada em) transformações mútuas entre diferentes jeitos de estar negro no mundo - frisa-se a noção de cosmoecologia, na qual estão reunidas cosmologia e ecologia, e os caminhos e destinos interligados de humanos, deuses, cabras, ervas, terreiros e quilombos (Despret 2016).

PALAVRAS-CHAVE: quilombos, religiões de matriz africana, relações humano-animal, cosmoecologia.

Trails of blood and honey: pilgrim draft of a black cosmos-ecology in southern Brazil - When following goats raised in a rural black community from the extreme south of Brazil to houses of Afro-brazilian religion in the metropolitan region of Porto Alegre, Rio Grande do Sul, this article intends to be a peregrine narrative (Ingold 2015) from a perspective of counter-identity (Anjos 2006) of the trails and zones of passage in which quilombos and terreiros create common cosmoecologies. In the intertwining of concrete multiplicities there is the sharing of what can be called a black cosmoecology, interlinking mutual transformations between different ways of being black in the world. The notion of cosmoecology is emphasized, in which are gathered cosmology and ecology, and the intertwined paths and destinies of humans, gods, goats, herbs, terreiros and quilombos (Despret 2016).

KEYWORDS: quilombos, Afro-Brazilian religions, human-animal relations, cosmos-ecology.

KOSBY, Marília Floôr (floorkosby@gmail.com) - Programa de Pós-Graduação em Antropologia Social, Universidade Federal do Rio Grande do Sul, Brasil. 


\section{APRESENTAÇÃO}

Este artigo foi escrito a partir de pesquisa etnográfica disposta a seguir os movimentos de conexões comerciais e produtivas entre o quilombo de Palmas, na zona rural do município de Bagé, no estado brasileiro do Rio Grande do Sul, e terreiros da Região Metropolitana de Porto Alegre, capital do mesmo estado. No rastro de animais, plantas e alimentos cultivados em quilombos para serem enviados aos terreiros das regiões mais urbanizadas, eclode um cosmo de seres vivendo vidas em aliança, multiplicando pactos entre viventes e vozes nos estudos de etnologia afro-americana. ${ }^{1}$

Segundo o Instituto Nacional da Colonização e Reforma Agrária (INCRA) do Brasil, existem aproximadamente três mil comunidades quilombolas no país. Tais comunidades são definidas pelo INCRA como grupos étnicos, constituídos, predominantemente, por população negra rural ou urbana, autodefinida de acordo com o parentesco, o território, as relações com a terra, a ancestralidade, as tradições e práticas culturais próprias. Atravessando esse conjunto de relações está o compartilhamento da experiência de escravização das populações de origem negro-africana trazidas à força para a América durante séculos de colonização: a formação de quilombos está diretamente associada a movimentos de resistência ao cativeiro e ao trabalho escravo, tais como a fuga para lugares remotos e de difícil acesso, as deserções de guerras e insurreições.

O Ministério da Cidadania considera povos e comunidades de terreiro como famílias, assim autodefinidas, predominantemente negras, vinculadas a casas de tradição de matriz africana (chamadas também de terreiros). A noção de família aqui possui sentido amplo, não nuclear, e os laços de parentesco são definidos seguindo uma genealogia iniciática na vida do terreiro, organizada a partir de uma ancestralidade de matriz africana, que rege cada casa e as linhagens de onde descende - o que não quer dizer que os laços de consanguinidade sejam aqui desconsiderados, mas combinados com outros. Há também a definição popular de terreiro como casa de religião de matriz africana, marcando a presença de suas práticas ancestrais de relação com o sagrado, também chamadas de religiões afro-brasileiras (candomblé, batuque, xangô, tambor de mina, dentre outras). No Rio Grande do Sul, as casas de batuque (ou nação), seguem os princípios do que se denominou terreiro. No que diz respeito à religiosidade, o batuque cultua os orixás como divindades ancestrais de matriz africana, que também são forças da natureza. ${ }^{2}$ Ademais, preocupa-se aqui em

I Este artigo é parte da produção acadêmica escrita durante o período em que a autora realizou pós-doutorado (PDE/Capes) no Departamento de Filosofia da Université de Liège, na Bélgica, entre os anos de 2018 e 2019.

2 Em muitas casas de batuque há o cruzamento com a umbanda e a quimbanda, que são religiões brasileiras de culto a entidades (espíritos), como caboclos, pretos-velhos e exus. 
lidar com terreiros e quilombos como comunidades tradicionais de matriz africana, enfatizando a noção de modo de vida (Ingold 2015).

Os intercâmbios de aves, caprinos, ovinos, ervas, mel, grãos, bem como os cuidados mútuos com essas culturas, esboçam coexistências partilhadas por meio de trilhas, que surgem de experiências negras corporificadas nos movimentos constantes de suas epistemes peregrinas (Ingold 2015). Tais cultivos são realizados nos quilombos, mas seguem regras de criação e manejo pautadas pelas exigências dos orixás e entidades cultuadas nos terreiros.

Interlocutores mais constantes deste trabalho - além de vetores dos fluxos mais intensos entre quilombos e terreiros - as cabras e bodes criados nos quilombos para participarem dos rituais de iniciação nos terreiros são criados e selecionados seguindo especificações de cor, sexo, reprodução, tamanho e espécie diretamente relacionados com as qualidades esperadas por cada orixá e seus filhos. ${ }^{3}$ Quanto às ervas e demais plantas, a Iyá Sandrali da Oxum, yalorixá ${ }^{4}$ e representante do Conselho Estadual do Povo de Terreiro do estado do Rio Grande do Sul, afirma que pelo formato das folhas de um guaco, por exemplo, há como saber qual o orixá protetor da pessoa que o cultivou. Isso se daria pelo manuseio e a convivência entre planta, ser humano, orixá e ambiente pensando-se que essas existências estão engajadas umas às outras, compondo multiplamente. Outro exemplo é o caso do quilombo da Mutuca, em Turuçu, que vende milho para uma cooperativa de terreiros da região de Pelotas, no sul do Rio Grande do Sul. Os grãos de milho em diferentes estados (cozidos, torrados, pipocas) são comida de vários orixás e utilizados para uma sorte de rituais, dentre os quais alguns serão descritos mais adiante.

Quanto ao mel produzido no quilombo de Palmas, durante minha pesquisa de campo recebi muitas encomendas para um terreiro de Pelotas. O mel - assim como o sangue e o azeite de dendê - é substância fundamental para o equilíbrio cosmológico, no batuque, para as relações entre "os vivos", "os mortos" e "os deuses" (Corrêa 2006). Além disso, o uso de mel nas oferendas aos orixás e nos rituais de iniciação agencia uma perspectiva política de não aniquilação da diferença, transportada na noção de "axé de doçura" como um jeito de estar no mundo em que "não se pode ter só bravura na vida" (Kosby 2015). No quilombo, atualmente, a produção de mel se dá por meio de caixas de abelha e subsídio governamental. Mas a relação com as abelhas e colmeias remonta aos ancestrais da comunidade que, escondidos no mato, se alimentavam de palmito e mel. Até hoje, há quem saiba reconhecer a presença das colmeias nativas dentro das árvores pelo zunido que fazem.

3 Filha-de-santo (yâ̂) ou filho-de-santo é a denominação dada à pessoa que participa da vida nos terreiros, tendo já passado por rituais de iniciação. É-se, portanto, filho de seu(s) orixá(s) e de seu pai ou mãe-de-santo.

4 Mesmo que mãe-de-santo. 
Esses dois domínios etnográficos, quilombos e terreiros, costumam ser abordados de forma isolada na maior parte da bibliografia do campo das pesquisas em ciências sociais sobre as populações afro-americanas. Neste artigo, entretanto, busca-se conhecer as possíveis histórias de "construção ativa de similaridades" (Despret 2007: 40) ${ }^{5}$ entre os modos de estar no mundo das religiões de matriz africana e os dos quilombos, operacionalizando-se essa mesma premissa para o "devir com" de humanos e não humanos (Despret 2007). Para isso, lança-se mão do conceito de cosmoecologia (Despret 2016), no qual estão reunidas cosmologia e ecologia, para dar conta dos caminhos e destinos interligados de humanos, deuses, cabras, ervas, terreiros, quilombos. Aqui, portanto, propõe-se o esboço de uma cosmoecologia negra, que entrelaça as transformações mútuas imanentes ao devir-negro dos corpos aqui envolvidos - sem ignorar as atualizações de suas singularidades.

Assim, partindo de pressupostos contraidentitários (Anjos 2006), atenta-se para o compartilhamento de fluxos cosmopolíticos - o que não pressupõe que se busque, entretanto, continuidades ou descontinuidades identitárias entre tais territórios, mas a possibilidade de cartografia de uma ecologia da vida (Ingold 2002) em comum. Pretende-se, assim, abordar como terreiros e comunidades negras rurais compartilham mundos na resistência ao racismo, às forças de aniquilação da diferença do Estado brasileiro e seus tentáculos colonialistas. As cabras serão, portanto, os corpos-território ${ }^{6}$ cujos movimentos nos levarão mais longe na tarefa de esboçar as transformações mútuas envolvidas na atitude epistemológica de, como diz Despret (2007: 41), "estender seu ser ao ser do outro".

Grande parte das discussões aqui apresentadas são impulsionadas pela tese de doutorado Alma-Caroço: Peregrinações com Cabras Negras no Extremo Sul do Brasil (Kosby 2017), que acompanhou, entre 2014 e 2017, os rastros das cabras quilombolas da comunidade de Palmas, desde suas perambulações pelas trilhas que atravessam a localidade do quilombo e sua vizinhança, até sua chegada à cidade de Alvorada, de onde são vendidas para participarem dos rituais de abate sacralizado nos terreiros da região de Porto Alegre. A referida tese coloca-se como desdobramento das pesquisas do Inventário Nacional de Referências Culturais - Lidas Campeiras na Região de Bagé/RS.

Os postulados metodológicos empreendidos para a realização da pesquisa aqui apresentada baseiam-se no intento de se construir uma etnografia peregrina (Ingold 2015), em contraposição ao postulado de etnografia multissituada (Marcus 2001), pois, ao contrário desta, não se realiza em diferentes

5 Tradução da autora. Todas as obras bibliográficas aqui citadas, originalmente em língua estrangeira ao português, serão traduzidas livremente.

6 Ou seriam corpos-terra? Se estendermos às cabras de Palmas a concepção do músico folclórico argentino Atahualpa Yupanqui de que "homem é terra que anda", tenho a impressão de que lidamos de maneira mais generosa com as imagens que nos suscitam essas vidas peregrinas. 
localidades, mas através, em torno de lugares, de um lugar para outro. Assim, pretende-se ultrapassar o que Ingold, em Estar Vivo: Ensaios sobre Movimento, Conhecimento e Descrição (2015), chamou de "lógica da inversão", uma lógica de fato sedentária, segundo a qual todo organismo é reconfigurado como expressão externa de um desígnio interior - a vida fica instalada dentro das coisas. Encontrar "aberturas" no mundo que permitam acompanhar os movimentos dos viventes entre terreiros e quilombos permite que se ultrapasse os limites impostos pelas políticas de identidade, que se preocupam mais em sedentarizar comunidades dentro de territórios do que em permitir que habitem o mundo conforme suas necessidades de mobilidade e intercâmbio. $\mathrm{O}$ objetivo de construir uma etnografia peregrina carrega de desafios a escrita de um texto antropológico peregrino, que se movimenta conforme as linhas de vida que aciona.

Outro eixo a ser deslocado é aquele que centraliza humanos como agentes por excelência do social. Pretende-se considerar outras espécies animais e vegetais como interlocutores da pesquisa, propondo-se, assim, a realização de uma antropologia menos antropocêntrica e instrumental, com viés pós-humanista (Digard 1999; Kirksey e Helmreich 2010; Haraway 2008) e pós-naturalista (Descola 2005).

Dentre os principais interlocutores da pesquisa aqui apresentada estão os seguintes moradores e moradoras da comunidade quilombola de Palmas, e suas respectivas cabritas: Dona Zair Franco, Dona Onélia Franco e Seu Alcíbio (moradores do Rincão do Inferno), Seu Pedro e Dona Neli Alves, os irmãos Leomar e Vanderlei Alves, Ana Luísa Soares, Fabiani Alves Franco (filha de Leomar).

O vizinho desta comunidade Teodoro Valente também foi visitado. ${ }^{7}$ Teodoro é o principal opositor à demarcação de terras quilombolas em Palmas. Tem cerca de 45 anos de idade, é branco. Também cria cabras, mas em larga escala, e faz a mediação com o aviário de Porto Alegre. Pode ser considerado um grande proprietário de terras, para os padrões da região, tanto no sentido agrário quanto no sentido de suas movimentações políticas - defende o desmatamento de mata nativa, a extração de minérios na região e o uso de agrotóxicos.

Outro interlocutor significativo foi o caminhoneiro e comerciante de animais Alfredo da Graça. ${ }^{8}$ Alfredo é um homem branco, tem pouco mais de 30 anos, e é um dos proprietários de um estabelecimento familiar de compra e venda de animais, na zona norte de Porto Alegre, ativo há mais de 60 anos. Apesar do contato estreito e cotidiano com pais e mães-de-santo de toda Porto Alegre e região metropolitana, Alfredo e seu tio Galvão não se consideram "de religião". Há cerca de 30 anos, a família compra cabras de Teodoro. As cabritas compradas em Palmas ficam hospedadas em Alvorada, cidade da região de Porto 
Alegre, onde Alfredo mora. Possuem clientes em Caxias, Canoas, Viamão e outras localidades.

Acompanhou-se também o babalorixá Pai Humberto de Bará Adague e seu filho-de-santo, o tamboreiro Gilmar de Ogum Avagã. Pai Humberto de Bará Adague é um homem negro de cerca de 50 anos, atualmente morador da Vila Quinta do Portal, na Lomba do Pinheiro, em Porto Alegre. Quando ele nasceu, sua mãe já era iniciada no batuque. Sua avó materna também. Ambas eram filhas-de-santo de Mãe Moça da Oxum, yalorixá da nação Oyó, que ficou muito conhecida em Porto Alegre - e que depois foi quem iniciou e aprontou Pai Humberto.

Gilmar é alabê (aquele que toca o tambor no terreiro) e aluno do curso de Ciências Sociais da Universidade Federal do Rio Grande do Sul. Nos conhecemos em uma oficina deliberativa sobre pluralismo religioso e relações étnico-raciais, promovida pela Fundação Joaquim Nabuco (PE), realizada em Porto Alegre com a colaboração do Núcleo de Estudos da Religião (UFRGS). Gilmar é um homem branco, tem cerca de 50 anos, e iniciou sua trajetória religiosa pela mão da falecida Mãe Jane de Oxum Pandá. Sua mãe biológica, sua avó e bisavó também eram de religião, de nação Oyó. ${ }^{9}$

A metodologia utilizada foi observação participante (Ingold 2014), com estadas no quilombo, visitas à empresa de venda de animais em Alvorada e Porto Alegre, uma viagem de caminhão com Alfredo entre esta cidade e Palmas, para o carregamento e transporte de cabras e carneiros. Além disso, realizaram-se entrevistas semiestruturadas com Pai Humberto de Bará Adague e Gilmar de Ogum Avagã, durante visitas de campo ao terreiro destes. Lançou-se mão, outrossim, de pesquisa bibliográfica em textos etnográficos e relatórios técnicos a respeito dos coletivos em questão.

\section{CHIBAS, CHANGUEIROS, ORIXÁS}

A comunidade quilombola de Palmas é composta por cerca de 30 a 40 famílias, todas ligadas por vínculos comuns de ancestralidade. Uma ancestralidade assentada na relação com a terra, na ocupação territorial da região em questão, além de laços de parentesco, compadrio e matrimonialidade. As famílias que

9 Cada casa de religião segue os fundamentos cultivados por seu dono ou dona. Entretanto, existe uma espécie de linhagem de santo, uma matriz (ou bacia) de onde vem os ensinamentos dos pais e mães-de-santo da nação a qual se pertence. No batuque há uma divisão por nações. Há referências a casas de nações jeje, cabinda, oyó, jeje e jeje com jexá (ou ijexá), para citar as mais recorrentes. Essas classificações fazem alusão a nações africanas, embora não haja necessariamente continuidade direta entre a nação de religião e sua correlata gentílica. Pai Humberto é da quarta geração de feitos no Brasil da nação Yorubá Oyó Mantu, também conhecida por nação Oyó. As diferenças entre as nações do batuque, observadas em primeira instância, se dão no proceder dos rituais, principalmente na velocidade dos toques de tambor e nos axés (cantos) entoados. 
constituem a comunidade são descendentes de trabalhadores negros escravizados das estâncias de pecuária da região. ${ }^{10} \mathrm{~A}$ área cuja demarcação de terras de uso coletivo foi reivindicada pela Associação Quilombola de Palmas está situada ao norte do município de Bagé. O reconhecimento definitivo do território quilombola ocorreu em fevereiro de 2017, quando o INCRA publicou portaria no Diário Oficial da União, reconhecendo como território de remanescentes de quilombos a área de 837.984 hectares compostos pelas localidades Rincão da Pedreira, Rincão do Alves, Campo do Senhor Ourique e Rincão do Inferno.

Em Palmas, o relevo ondulado e fortemente ondulado, por "coxilhas" e "cerros", com altitudes entre 200 e 300 metros, o solo composto por frequentes afloramentos rochosos, por "lajes de pedra", "perais" e "paredões", densa vegetação arbórea, os "matos", são em linhas gerais descrições físico-geográficas e paisagísticas que se contrapõem à imagem hegemônica que se convencionou ter das regióes marcadas pela comarca pampiana, quais sejam, as vastidões de pastagens, várzeas e planícies, povoadas por extensos latifúndios, grandes rebanhos bovinos e seus pastores/caçadores, os gaúchos (Kosby, Lima e Rieth 2017).

A expressão "comarca pampiana" foi cunhada pelo pensador uruguaio Ángel Rama para descrever a região da fronteira Brasil/Uruguai como uma zona de compartilhamento cultural, sem dividi-la dicotomicamente em noções como fronteira geopolítica/fronteira cultural ou nação/região. Para Aldyr Schlee (2014), esse espaço fronteiriço é peculiar pela permanência de uma cultura periférica comum, dentro de limites nos quais os referenciais de delimitação territorial foram (e ainda são) definidos - cultural e linguisticamente - pelo processo decadente de exploração pecuária da criação extensiva de gado no pampa, mesmo processo em que está forjada (e sucumbida) a figura do gaúcho.

Atualmente, a criação de caprinos, a produção de mel, a feitura e venda de doces, o acesso a crédito rural, à aposentadoria e aos direitos vinculados ao estatuto de produtor rural - acessados principalmente a partir da formação da Associação Quilombola - apontam para outras possibilidades de sustento e manutenção da vida na localidade. As contendas fundiárias acirradas pelo reconhecimento das terras quilombolas fizeram com que muitos proprietários rurais brancos da região, que antes contratavam, ou melhor, solicitavam os serviços campeiros dos moradores do quilombo, deixassem de fazê-lo, como forma de retaliação. Assim, as famílias quilombolas adquiriram a possibilidade

10 A bibliografia historiográfica aponta para a significativa presença de pessoas negras dentre os contingentes de trabalhadores das estâncias (fazendas de criação de gado bovino) e charqueadas (estabelecimentos de manufatura industrial de carne bovina salgada), na região do pampa, durante e após o período de vigência oficial do regime escravista no Brasil. Ver Vechia (1994), Maestri (2006 [1984] e 2008), Osório (2005) e Palermo (2013). 
de usufruir de forma sustentável dos recursos naturais do território que habitam (e onde habitaram seus ancestrais), mas foram tendo suas relações de trabalho e sustento cerceadas pelos vizinhos, que também se organizaram, só que a partir de pautas "ruralistas", ${ }^{11}$ para dar continuidade às investidas historicamente insistentes de capturar e submeter as possibilidades de criação de vida autônoma e digna dos coletivos negros aos paradigmas agropastoris latifundiários. Uma ocupação comum na região, vantajosa para os contratantes e não para os prestadores de serviço, é a chamada changa. O changueiro faz serviços gerais rápidos pelas estâncias da região (conserta arames, limpa algum campo, cuida de algum animal, esquila alguma ovelha, corta lenha, carneia, etc.), sem vínculo empregatício ou salarial, em troca de valores ínfimos em dinheiro ou de algum "pedaço de carne".

Segundo o Relatório Sócio, Histórico e Antropológico da comunidade quilombola de Palmas, Bagé/RS, a itinerância é uma condição comum aos negros campesinos. As narrativas sobre os fundadores da comunidade de Palmas semantizam as noções de fronteira e escravidão: as fronteiras entre Brasil e Uruguai não estavam definidas durante os três primeiros quartos do século XIX, e a presença brasileira ao norte do rio Negro era agropastoril e utilizadora de mão de obra escrava (INCRA; UFRGS 2007). Aqueles que escapavam criavam "quilombos em matos de difícil acesso", e alguns criavam mais de um quilombo em matos diferentes, mudando-se de dias em dias para não serem presos. Há relatos de ranchos construídos por escravos fugidos dentro do mato, esconderijos em ilhas dentro do mato sobre o rio Camaquã.

Os constantes deslocamentos impostos por forças de opressão racial constituíram a comunidade de Palmas. O que era estratégia de aniquilação e exploração da presença negra na região, tornou-se a forma possível de existência da comunidade e de sua permanência no local:

“[...] os quilombolas da região de Palmas promoveram um processo de ocupação territorial gradativa, por meio da exploração de mão de obra escrava ou livre negra, denominado de 'desterritorialização relativa', uma vez que os quilombolas da região deslocam/migram, no período escravocrata, entre estâncias fugindo ou retornando de contexto de guerrilhas; trocando de campos como agregados; deslocando-se com as famílias entre trabalhos sazonais com as colheitas de trigo, arroz ou em atividades extra-

11 Termo utilizado para designar pautas que representam interesses oligárquicos de produtores rurais defensores do latifúndio, da monocultura, do uso de agrotóxicos e contrários à reforma agrária, à delimitação de terras indígenas e quilombolas. No Brasil há uma frente parlamentar ruralista, a chamada bancada ruralista ou bancada do boi, que atua no Congresso Nacional em defesa dos interesses desses produtores rurais. Nas últimas eleições federais, a associação entre as bancadas evangélica, armamentista e do boi ficaram mais evidentes, configurando o que se popularizou chamar de bancada "Bíblia, Boi e Bala" (BBB). 
tivistas, sobretudo na produção de lenha e carvão, paralelo à produção de roças." (INCRA; UFRGS 2007)

A manutenção dos rebanhos de cabritas é uma das poucas atividades pecuárias viáveis para a comunidade quilombola de Palmas, justamente porque esses animais são profundos conhecedores dos matos e suas trilhas, das ervas comestíveis, e destros transeuntes nos perais. Por se alimentarem de brotos e do mato - pastando somente em casos de não haver alternativa - a necessidade de alimentá-las com milho ou ração se faz menos urgente. Dentre as plantas mais abundantes nos matos de Palmas, as cabritas comem folhas e brotos de pitangueira, cambará, aroeira branca, São João, embira. Esta última é venenosa em determinadas épocas do ano, e as cabritas sabem disso, comendo-as só quando possível. Teodoro Valente diz que estes animais são muito seletivos, pois, embora pareça que "comem tudo o que veem pela frente", escolhem muito bem as ervas, sua idade e época do ano. Seu Alcíbio diz que a carne de cabrita é mais saudável do que as outras, pois tudo o que ela come é chá. Numa ida ao mato para chamar as cabritas com Ana Luísa e as crianças, percebi que estas vinham pelo caminho comendo as folhinhas das mesmas árvores que as cabritas comem, as mesmas com as quais Ana Luísa faz chá para acompanhar bolo ou torta frita, ou para curar enfermidades.

Por quase não pastarem, não comerem gramíneas próximas do chão, as cabritas evitam serem contaminadas por verminoses. Raramente morre uma cabrita por doença ou ataque de predadores, em Palmas. O mais comum de acontecer é morrerem filhotes durante grandes geadas. Andar pelos perais oferece solo seco, evitando a doença mais recorrente entre as cabritas: as frieiras nos cascos.

Segundo Leomar, as cabritas podem dar até três crias por ano - sendo comum o parto de gêmeos ou trigêmeos. Quinze dias depois de parir ela já pode emprenhar de novo, desde que esteja bem nutrida, ou seja, que haja espaço e alimento suficiente para todo o rebanho. Colocar muitos caprinos em um pequeno espaço significa menos reprodução dos mesmos. Nas cabritas não se percebe um cio periódico, podendo copular e emprenhar caso haja um bode por perto. A reprodução é controlada tirando-se os bodes do rebanho, em determinados períodos, e é controlada para que os recursos naturais de alimento não se esgotem. A venda dos animais para os terreiros fica dependendo de não estarem as cabritas com filhote "no pé", ou seja, com filhotes recém-nascidos.

Com quatro meses de idade um cabritinho já pode "se governar", ou seja, comer sem precisar da mãe e querer cobrir (copular com) as cabritas (que com cerca de seis meses já permitem cobertura). Quem me fala em cabrito "se governar" é o comerciante Alfredo, durante a viagem entre Alvorada e Palmas. Alfredo está entre mundos, traduz um universo pelo outro. No batuque 
do Rio Grande do Sul, outro campo pelo qual Alfredo circula, também há a expressão "se governar". A pessoa pode se governar depois de pronta, de ter assentado todos os orixás no corpo e na pedra (acutá) e de ter recebido os axés de ifá e obé, búzios e faca, respectivamente. A pessoa que se governa pode "cortar" para si e para filhos e/ou afilhados de santo, ou seja, pode usar a faca para iniciar outras pessoas, vertendo o axorô (sangue sacralizado) do corpo de um animal para o corpo de um ser humano e para os objetos rituais. No ritual do "corte" ocorre um tipo de abate sacralizado, do qual as cabras (algumas ovelhas e carneiros) de Palmas participam depois de vendidas para os terreiros. Quando alguém "corta para seus pais" quer dizer que essa pessoa está atualizando a presença dos seus orixás pelo seu corpo, o seu axé. ${ }^{12} \mathrm{O}$ "corte" é parte de uma "obrigação", ritual no qual se "dá de comer ao(s) orixá(s)". Logo após o "corte", a pessoa vai para o "chão", que é um período de resguardo, durante o qual o orixá come na cabeça, ao mesmo tempo em que no seu filho ou filha se nutre uma pessoa nova, renovada.

Em Aspectos Sócio-Jurídicos sobre Intolerância Religiosa, Laicidade do Estado e Direito ao Culto Frente às Tradições de Matriz Africana, Winnie Bueno (2015) traz uma pertinente descrição desses rituais no contexto da vida nos terreiros do Rio Grande do Sul:

"A imolação de animais nas expressões religiosas das tradições de matriz africana é a forma com que se estabelece a comunicação entre os adeptos e as divindades cultuadas, um fundamento sagrado com múltiplos significados míticos que se configuram enquanto pilares dessa religião. Não obstante, o abate sacrificial é uma forma de renovação das relações entre humanos e animais, em que ambas formas de vida são colocadas em continuidade e equidade. É um ritual de renascimento em que a importância da vida animal supera o princípio do consumo para a alimentação humana. Ao colocar animal e humano em extensão, implicados um no outro, esse ritual põe o homem em contato com potências complexas de sua existência enquanto 'ser vivo'. Assim, o abate sacralizado de um animal também encerra o ciclo de uma vida humana, que se reinicia fortalecida pela nutrição dos deuses e

12 Em termos genéricos, axé é a energia vital que gere o universo, refere-se à energia que torna vivo tudo aquilo que tem vida, que existe. Tendo em vista que, na perspectiva afro-religiosa, todas as coisas podem ser dotadas de vida, um dos princípios fundamentais de sua composição ritualística e filosófica é a canalização e o controle do axé, da força que, vertendo dos elementos da natureza, atravessa seus fluxos por todo o universo, precisando ser corretamente manipulada para que a vida mantenha o sentido que se espera. O vocábulo "axé" também é utilizado para se referir ao fundamento, o conhecimento, que governa cada casa ou linhagem, tornando operativo os poderes e a energia vertida das divindades. Uma mãe-de-santo, seus filhos e demais descendentes, todos recebem o mesmo axé, a energia do orixá mais velho - neste caso, o da matriarca. Isso não exclui o fato de cada um ter o axé de seu próprio orixá e este tocar nos demais (Kosby 2011). 
da comunidade. Mas isso só é possível graças a uma cosmologia que enxerga a vida como fenômeno coletivo, prevista pela interdependência entre animais humanos e não humanos, plantas, matas, águas, solo, ventos, enfim a natureza e o meio ambiente." (Bueno 2015: 43)

As cabritas são membros da comunidade de Palmas. Com as pessoas e com o lugar mantêm relações de vivência fundamentais para que as formas de socialidade que ali eclodem sejam intensidades capazes de criar fluxos de existência com aquele lugar. Ninguém soube ao certo me dizer quando as cabritas chegaram por lá, mas todas as pessoas com quem conversei me disseram que seus pais ou avós já criavam caprinos. Dona Maria Eva Alves, em entrevista aos pesquisadores da UFRGS (Gehlen e Bittencourt Jr. 201 1), conta que conter os cabritos é muito difícil, que sempre passou trabalho com esses animais. A necessidade de contê-los tinha como principal objetivo evitar que destruíssem roças e lavouras ou fugissem. Faziam-se cercas de rama, de pau a pique, moirões e cercas de pedra.

Houve, em 2005, um incentivo do Programa RS Rural para diversos tipos de atividades produtivas que teriam a ver com a realidade da comunidade, dentre elas, a caprinocultura, a apicultura, a ovinocultura. ${ }^{13}$ Nessa ocasião, vários moradores optaram por criar cabritas porque são animais que "não dão muito trabalho", quase não adoecem, não precisam de grande investimento para se reproduzirem, requerendo apenas uma certa atenção à manutenção do convívio com os humanos, para não se afastarem muito da casa de quem as cria. Enfim, os que optaram pelas cabritas já sabiam como conviver com estes animais. Aqueles que hesitaram em escolher "as cabritas do governo", mas acabaram aceitando o desafio de criá-las, ao invés de optarem por outros subsídios estatais, no início tiveram dificuldade para lidar com a itinerância dos bandos. Seu Pedro, tio de Vanderlei e Leomar, se queixava de ter que andar "gastando o cavalo", subindo e descendo cerro atrás de cabrita.

As cabritas, segundo Seu Alcíbio, gostam das pedras, que abundam em Palmas, e gostam de andar: "Para elas não tem campo... para elas é caminhar... nem sei como permanecem aí na volta..." (Bueno 2015: 1 15). Quando conheci Seu Biqui, cerca de dez anos depois da entrevista acima, ele já parecia saber o que fazia as cabritas não se afastarem definitivamente. Dizia-me: "não há bicho que a boia não amanse". As cabritas de Palmas devem ser "amansadas" com mais frequência do que as ovelhas, por exemplo. Seu Biqui tem umas quatro ovelhas que aparecem de manhã na volta da casa para receberem comida, sem precisarem ser atraídas. Se fossem cabritas teriam que ser chamadas, ou

13 Programa desenvolvido pela Secretaria da Agricultura e Abastecimento do Estado do Rio Grande do Sul, a partir de empréstimo do Banco Mundial (BIRD), com a contrapartida do Estado do Rio Grande do Sul. 
ficariam devorando os brotos e folhinhas do mato - ou ainda a roça. Ele conta que tem uns cabritos "guaxos" na volta da casa (órfãos criados perto dos humanos), mas que os "araganos" (afastados do convívio humano, andarilhos), soltos mato adentro, são mais de 80 animais, assinalados na orelha, mas sem marcação no couro. ${ }^{14}$

Conforme Dona Zair, “as cabritas não têm paradeiro, são danadas”. A estratégia delas para se manterem alimentadas é a itinerância pelos matos e perais. Pode-se perceber que os matos mais fechados, mais densos, acabam por ficar "limpos" até certa altura, pois as cabritas vão comendo a vegetação que está ao seu alcance. E embora não haja necessidade de grandes investimentos financeiros na manutenção do rebanho, é fundamental que as cabritas sejam manejadas pelo menos uma ou duas vezes por semana, para que não fiquem "bagualas" (xucras, araganas, asselvajadas), já que sua condição de domesticadas, ou não, não é definitiva. Quando "bagualas", custam para atender ao chamado com oferta de milhos. Entocam-se nos matos, ou saem a caminhar pelas pedras e não voltam para os locais de referência, onde costumavam encontrar-se com os humanos - criam outros locais de referência. Há uma certa autonomia com relação à subsistência e a constante necessidade de os humanos reforçarem os laços de convivência com os animais. Pode-se dizer de que as cabritas também esperam dos humanos que eles não se "asselvagem" em relação a elas.

No rincão do Inferno a topografia composta por cânions de pedra (que formam o vale do rio Camaquã) e as matas densas, tornam muito árduo o trabalho de buscar as cabritas, estas se tornando "selvagens" pela vida no mato, "por aí”. Dona Onélia tem vontade de criar umas cabritas guaxas porque os guaxos quase não se dispersam. As cabritas enquanto muito próximas dos humanos, tais como guaxas, andam por cima das camas, das mesas, dos sofás, se deixam abraçar, beijar. No entanto, é só passarem alguns dias sem contato com as pessoas, ou sem receber comida, que já rumam para os matos, para as andanças, e logo se tornam tão bravias que só estratégias de caça são capazes de trazê-las de volta para o convívio humano. Às vezes, quando alguém aparece com arma, faz-se uma caçada e se consegue trazer um cabrito para casa, para comê-lo. $\mathrm{Na}$ caça alveja-se o animal à distância, já no abate doméstico, usa-se a faca.

É raro carnear e comer um guaxo, sendo bem mais comum abater cabritos mais os machos do que as fêmeas - que ficam afastados do convívio humano. Essa aproximação/afastamento, como já foi visto, é negociada constantemente. Fabiani Franco lamenta ter tido que vender suas duas guaxinhas brancas para um caminhoneiro, que buscava por cabras desta cor para vender a uma casa de

14 Assinalar é fazer um recorte na orelha do animal com a faca, fazendo um desenho que identifique o dono do rebanho. Há quem marque o couro dos animais com uma insígnia de ferro quente, como se faz com o gado. Esta prática é quase inexistente no quilombo. 
religião. Como eram as únicas brancas e a família de Fabiani estava precisando vender, foram-se as guaxas para um terreiro da cidade de Uruguaiana.

Na periferia de Porto Alegre, Pai Humberto de Bará Adague evita manter as cabritas, cabras, bodes, cabritos, ovelhas, carneiros, enfim os animais de quatro pés destinados aos orixás, perto de casa. Pede para o vendedor entregá-los no dia da obrigação, assim não se criam afetos mais profundos com esses animais - nem afetos de amizade e carinho entre humanos e aqueles espécimes mais dóceis, nem brigas e disputas corporais entre homens e bodes furiosos. No primeiro caso, evita-se que se tenha dó ou pena de matar o animal que o orixá vai comer, sob a possibilidade deste rejeitar a comida que lhe é ofertada e o animal não poder ser abatido; no segundo, evita-se que carneiros machuquem às cabeçadas aqueles que com eles lidam, e que bodes "sexualmente vorazes" e violentamente habilidosos nas disputas corporais contra a contenção, machuquem fêmeas e machos das demais espécies - seja pelas tentativas reiteradas de cópula forçada, inclusive com ovelhas e cabritos, seja pelos seus revides às ações humanas contentoras.

Para Pai Humberto, "o animal tem que se oferecer em sacrifício". Assim, se ele não aceita comer o milho ou o pasto que lhe oferecem enquanto é encaminhado para o abate, já dentro do salão do terreiro, é porque o orixá também não quer comer, devendo-se suspender a imolação do animal. Se este se abaixa na frente do quarto de santo também deve-se suspender o abate; se a cabrita ou a ovelha berrarem, podem estar prenhas (observam-se as tetas, para ver se estão inchadas) e não se mata animal prenhe; se a ave bate as asas na hora do "corte" também não pode ser abatida. Todos esses são sinais de que o orixá rejeitou a oferta. Pai Humberto conta que pode acontecer de o cabrito ir sozinho, mas também de o pai-de-santo sentir na hora que não é para matar e mandar soltar.

Pai Humberto não abate animal que não tenha escolhido. Não encomenda bicho por telefone, não compra sem olhar. Para ele, o animal se torna "sagrado" no momento em que é escolhido, porque é quando ele se identifica com o animal e consegue encontrar correspondências entre este e o orixá do filho que fará a obrigação:

"Eu tenho que olhar para ele e ver que ele é para aquele determinado orixá [...]. Digamos, o Fabrício é filho de Oxum. Em outubro ele vai cortar para seu orixá, como vários filhos meus vão fazer. Eu tenho que olhar e ver que aquela ali é a cabra que será para a Oxum dele [...]. Eu tenho que saber que aquele ali tem a cor, o tamanho, ideal para cada orixá." [Entrevista em 08/07/2017]

Desde o momento em que o comprador avisa Leomar e Fabiani que não devem capar os bodes, lá no quilombo, estes animais já podem ser vistos como 
para algum orixá - neste caso podem ser para Ogum, já são de Ogum, já são Ogum, aos olhos de quem é de axé. Na lista de compras de Alfredo constam, por exemplo: "duas cabritas amarelas para Oxum", "uma cabrita mocha para Obá".

$\mathrm{Na}$ casa de Pai Humberto, Oxum, Oxalá, Iansã, tem que comer cabrita "parideira", que já tenha reproduzido. Isso porque Oxum e Iansã são mães e Oxalá tem parte na procriação. Ele é o único orixá homem que come cabrita e galinha, fêmeas e brancas. Como Oxalá e Oxum são os progenitores da maioria dos outros orixás, Oxalá come fêmea porque ele rege a fertilidade de Oxum. Iemanjá também é mãe, mas come ovelha branca. Xangô come carneiro branco com bastante chifre. Bará, Ogum e Ossanha comem cabrito com chifre, mas se o Ogum ou o Bará forem de rua (Avagã e Lodê), devem comer bode. Nenhum desses orixás pode comer filhotes. Mas os Ibeijis e o Bará agelu, que são orixás crianças, podem comer cabritos pequenos. Xangô e Oxum de Ibeji comem, respectivamente, carneiro e cabrita pequenos. A orixá Obá só come cabrita sem chifre, que não tenha tido cria e, de preferência, que sejam virgens; não pode nem ter esboçado chifre. Odé e Otim, que são um casal, devem comer um casal de leitões. Todos os machos devem ser inteiros, ou seja, não podem ter sido capados.

Todos devem comer um espécime de maior tamanho possível, o que, segundo Pai Humberto, é uma característica da nação Oyó: "nós não somos feitos com animais pequenos, só os enormes, cabras, bodes". E não importa o tamanho do corpo da pessoa, o importante é a fortaleza que se ganha ao alimentar o orixá com um animal viçoso.

No que diz respeito às cores dos animais, as definições vão ficando menos exatas. Parte-se de uma cor ou característica, e delas a definição vai variando: "um bode escuro para Ogum", ou, "[para Obá] Eu procuro branca, cinza, que é mais o arquipélago de Obá. Até uma amarelinha, de repente.” Pai Humberto fala em arquipélago para designar o conjunto de domínios que o orixá abrange. A gestação e a reprodução, por exemplo, é um domínio por onde passa Oxum.

Para evitar que se abatam muitos animais e que "corra muito sangue", o que exige controle dos vazamentos - assim como grandes demandas de dinheiro, tempo e gente - alguns orixás "comem juntos". Por exemplo: Ogum, Ossaim e Xapanã comem juntos. Estão estes orixás muito presentes nos matos, nas folhas ou ervas, na cura e nos ferimentos. ${ }^{15} \mathrm{O}$ bode de Ogum é "acinzentado, meio malhado, meio preto/meio branco". Se a pessoa for cortar para Ogum, Ossaim e Xapanã comem este bode "acinzentado...". Se for cortar para Ossaim, o bode é "meio branco", e Ogum e Xapanã também comem. Se o corte é para Xapanã, o bode é "um pouco mais escuro, quase preto", Ogum e Ossaim aceitam

15 Na etnografia de Norton Corrêa, há referência a um ritual feito nas casas de batuque, no qual "os orixás vão para a guerra ajudar o Xapanã que está apanhando da polícia” (2006: 191). A imagem mítica de Xapanã é a de um homem com o corpo coberto de palha, para esconder as chagas que traz na pele. 
também. E pode acontecer de Oxalá comer a mesma cabrita que Oxum ou a ovelha de Iemanjá, pois "andam juntos". Assim, quando Gilmar vai escolher o bode de seu Ogum de cabeça, evita que ele seja "mais branco do que preto", porque branco é um domínio de Oxalá, e é como que um desrespeito invadir o domínio de outro orixá, ainda mais Oxalá, que é um orixá velho e especial na hierarquia do Orumalé.

As fronteiras entre os domínios dos orixás se interpenetram em muitos momentos. Há sempre um "meio", "um quase", "um pouco mais", que permitem os vazamentos e as possibilidades de variação que os singularizam sem deixarem de estar junto com os demais. Mesmo a individuação supõe a composição com algo mais, esboçado na impossibilidade de definir a exatidão dos matizes sem que se perca uma alteridade que é fundante para esses seres múltiplos. ${ }^{16}$ Talvez por isso Pai Humberto enxergue o candomblé da Bahia não como outra religião, diferente do batuque, mas como outra nação, diferente das diversas existentes no Rio Grande do Sul.

A questão dos domínios, dos fluxos de intensidades e da canalização destes está também diretamente relacionada com os fluxos de axorô e as intensidades que atualizam. Nos rituais de abate sacralizado, a lógica do "arquipélago", dos vazamentos, se inverte e as fronteiras entre domínios passam a ser bem delimitadas. É preciso saber fazer o corte do jeito específico para cada finalidade, ou seja, para alimentar o ser com quem se espera reforçar os laços, sob pena de a vida se desorganizar de forma drástica ou de o ritual não ter a eficácia esperada. ${ }^{17}$ Para Pai Humberto, não se pode deixar sangue "correndo por correr". Não é possível matar um animal para comer no pátio de casa, pois o sangue escorrendo "chama outros seres" para comê-lo, caso não se faça o ritual de oferecer para um orixá ou entidade. Conta que, certa vez, estava em um sítio e precisou matar uma ovelha para fazer churrasco. Preferiu usar uma arma de fogo, pois a faca transmitiria axé, já que a sua mão tem axé. ${ }^{18}$

\section{"O CABRITO NÃO PODE PISAR ONDE MIJA": EPISTEMES PEREGRINAS}

A "rusticidade", a "plasticidade", das cabritas - características enfatizadas no quilombo Palmas - não estão dadas pelos seus corpos desengajados do ambiente, principalmente do chão onde pisam. O contrário também pode ser

16 Sobre multiplicidade nas religiões de matriz africana ver Bastide (2001, 1971), Goldman (2005). Especificamente sobre o batuque do Rio Grande do Sul, ver Barbosa Neto (2012).

17 Em "A sorte da carne: Topologia animal nos Andes meridionais" (Pazzarelli 2017) os animais de criação que são abatidos e carneados pela comunidade não podem sentir dor ao morrer, nem relutar. A faca tem que ser bem passada, sob o risco de haver "contaminação" entre mundos que devem ser constantemente apartados.

18 Sobre a noção de participação nas religiões brasileiras de matriz africana ver o artigo "Algumas considerações em torno de uma 'lavagem de contas' " (Bastide 1973). 
dito delas, de não serem bichos fáceis de criar, o que muito se ouve dizer na cidade. Pai Humberto de Bará conta que antigamente havia yalorixás e babalorixás que tinham algum animal em casa, mas o crescimento da cidade acabou por confinar o espaço, tanto para os humanos quanto para os cabritos (no masculino, na cidade). Ele conta que cabritos são bichos difíceis de criar porque eles não podem pisar sobre a própria urina, o que desenvolve um tipo de verminose, que pode ser fatal - no quilombo fala-se em frieiras causadas pela umidade. Isso demanda muito espaço para deslocamento.

As descrições de Pai Humberto nos ensinam também sobre o quilombo e as controvérsias de se exigir que as cabritas lá fora fiquem em abrigos, pisando sobre serragem. Não há produção de cabritas para o mercado de carne (commodity) na comunidade quilombola de Palmas, tampouco a venda de cabrita para as religiões de matriz africana gera rendimentos que permitam investir em outras formas de manejo. Os padrões de produtividade e sanitários, exigidos pelos programas estatais de incentivo à produção rural e permanência no campo, são praticamente inalcançáveis para a comunidade quilombola, tanto pelo investimento de capital financeiro quanto pelas transformações na vida que causaria a sedentarização dos caprinos em mangueiras, a alimentação por comida comprada (ração, milho) e o uso de medicamentos. Isso implicaria em uma sedentarização das pessoas também, que passariam os dias em função de juntar cabritas, colocar no estábulo, alimentar, dar remédio, etc. Às cabritas que são consumidas domesticamente e pelas casas de religião, "o mato sempre deu tudo" que é preciso.

A presença de mediadores estabelece uma distância entre os consumidores e os criadores. Tanto os religiosos quanto os quilombolas ficam à mercê dos preços estabelecidos pelos mediadores, e há por parte de alguns produtores brancos da região a intenção de apagar a origem das cabritas quando estas vêm do quilombo - misturam os animais dentro do caminhão e dizem não saber quais vêm do quilombo ou quais vêm de produtores brancos. Assim, justifica-se a frase dos técnicos estatais e ruralistas: "os negros de palmas não produzem nada" - mesmo que os próprios ruralistas estejam ganhando dinheiro com as cabritas da comunidade quilombola. Alfredo compra cabritas de Teodoro Valente para vender na região metropolitana. Teodoro compra dos moradores do quilombo por cerca de 130 reais e revende para o mercador por 200 . O preço dos animais mais que triplica até chegar nas casas de religião: se no quilombo são vendidos por 130 reais cada um, na cidade eles podem chegar a 600 reais cada. ${ }^{19}$

19 Em 2017, o Conselho Estadual do Povo de Terreiro do Rio Grande do Sul montou, junto com a Regional Emater de Porto Alegre (Empresa de Assistência Técnica e Extensão Rural), um projeto piloto de estabelecimento de redes de mercado entre quilombos rurais e terreiros. O Conselho se encarregou de fazer um inventário de demandas dos terreiros por itens como milho, plantas, galinhas, cabritos, enquanto a Emater esteve responsável por fazer um levantamento daquilo que cada [continua] 
Alfredo não traz muitos cabritos de uma só vez para seu terreno em Alvorada, por causa da umidade, quando em épocas de muita chuva - era necessário cobrir com serragem o chão do galpão onde os animais ficavam, no interim entre chegar de Palmas e irem para os terreiros. Essa característica não impede que o bode urine nas patas da frente e esfregue-as na barba para atrair as fêmeas quando estas estão no cio - daí seu famigerado mau cheiro. O que parece concatenar as análises etológicas de Pai Humberto e dos quilombolas e seus vizinhos é a constante desterritorialização (parcial) dos cabritos, que estão sempre em outro lugar (embora não deixem de estar "pela volta").

Outra controvérsia que permeou a pesquisa advém do Projeto de Lei n. ${ }^{\circ}$ 21/2015, proposto na Assembleia Legislativa do Rio Grande do Sul pela deputada evangélica e ativista da proteção animal Regina Becker Fortunatti, que visava proibir o abate sacralizado de animais nas casas de religiões de matriz africana deste estado. O projeto de lei protocolado pela deputada Regina Becker não foi um fato isolado, nem no Rio Grande do Sul, nem na esfera nacional. ${ }^{20}$ Tais atitudes institucionais de perseguição contra as religiões de matriz africana no Rio Grande do Sul e no Brasil têm sido frequentes, pelo menos nos últimos dez anos (Oro 2005; Oro e Bem 2008; Goldman 2015b).

Nenhum dos interlocutores do quilombo diz possuir conhecimento sobre o que acontece nos terreiros para onde seus animais são vendidos. Dona Onélia, inclusive, tem certa proximidade com uma religião neopentecostal. Fabiani, por outro lado, traz uma perspectiva comparativa entre o abate nas casas de religião e a indústria frigorífica. Não tem dúvidas de que a demonização do abate nos terreiros é mais uma investida racista contra os modos de viver negros, já que é impossível acreditar que as pessoas que se mobilizam contra a presença de animais nos rituais afro-religiosos estejam mesmo indiferentes às origens sociais de quem pratica essas religiões. Diz que se tais movimentos de proteção dos animais fossem mesmo engajados pela manutenção da vida, e fora de qualquer semiótica conservadora racista, estariam investindo contra a barbárie da indústria frigorífica, que sacrifica animais e humanos.

Em Diez Gritos sobre la Campaña contra las Religiones de Matriz Africana, Marcio Goldman (2015b) afirma a existência de duas semióticas, que sustentam tais

quilombo (e algumas aldeias indígenas) produz. Questionada por mim sobre a possibilidade de incluir Palmas no circuito do projeto, uma técnica da Emater de Porto Alegre diz que os quilombolas de Palmas estão ilhados, que os técnicos da Emater Regional não conseguem prestar assistência sem serem retaliados na cidade. Ela acrescenta: "rodo o Rio Grande do Sul inteiro, de comunidade quilombola em comunidade quilombola, há anos, e Palmas, para mim, é a cara da escravidão". Fala isso por causa da forte pressão que os latifundiários exercem contra a comunidade e contra aqueles que se aproximam dela. De fato, a comunidade estava sem assistência técnica e só voltaria a tê-la, segundo os responsáveis regionais, "depois que cessassem os conflitos fundiários".

20 Advogada, ativista na defesa dos animais, ex-secretária especial dos direitos animais na Prefeitura de Porto Alegre (SEDA), membro da Igreja Batista Filadélfia e esposa do prefeito de Porto Alegre, José Fortunati. 
campanhas, "uma reacionária (os evangélicos em geral, de todas as cores) e uma moderna (os ecologistas, em geral brancos)". Para o autor, a primeira supõe que as religiões de matriz africana estão erradas porque acreditam e cultuam seres maléficos que, erroneamente, consideram benéficos. A segunda, que traz o discurso sobre os direitos dos animais, carrega neste a "certeza" de que as práticas sacrificiais das religiões de origem africana são "falsas", no "sentido moderno de que eles não são direcionados a nada nem a ninguém - uma vez que seriam o resultado da ilusão, do erro". A semiótica moderna "aceita" com condescendência as práticas que considera ilusórias, mas quando estas tocam suas verdades autoproclamadas universais, são combatidas com violência. Ambas, segundo Goldman, seriam as duas faces de uma mesma moeda de intolerância.

A yalorixá Sandrali De Oxum, em depoimento no documentário Tem Comida de Negro Aqui, enfatiza a relação que o povo de terreiro possui com os animais e as peculiaridades que isso traz para o abate e a produção de alimentos. Segundo a yalorixá, um negro "não mataria a pauladas o animal, que é uma extensão do seu corpo". O abate de animais, conforme as práticas das tradições de matriz africana, deve ser por corte com faca das veias jugulares do pescoço e por sangria rápida. ${ }^{21}$

Percebe-se que as investidas racistas e discriminatórias de projetos que visam aniquilar a presença potente das religiões de matriz africana também atingem, direta e drasticamente, a vida de comunidades negras rurais das regiões sul-rio-grandenses de Porto Alegre-Viamão-Alvorada, Pelotas-Canguçu-Turuçu e Bagé-Uruguaina-São Gabriel. Porque, em muitos casos, os animais que participam dos rituais de iniciação no batuque são oriundos de comunidades negras rurais. A atualização da historicidade das raças nos corpos de animais e humanos coloca batuqueiros e quilombolas como expostos a um mesmo fluxo de experiência da violência colonial e, ao mesmo tempo, como cúmplices nas estratégias de resistência a tais violências. Cabras, quilombolas, batuqueiros em devir-negro.

Mesmo os intervalos entre o quilombo e o mercador, entre Palmas e os terreiros, são preenchidos pelos movimentos de corpos em cuja historicidade irrompem como negros. O intervalo por onde transita o mercador, dono do aviário que faz o comércio dos animais para as terreiras, é carregado de intensidades transformadoras muito potentes para as cabritas - lugar de tensões, de imobilidade forçada e de desterritorialização. Quando as cabritas, cujo modo de fazer conhecimento no mundo é um modo peregrino, são transportadas

21 A etnografia de Pazzarelli (2017) aborda a relação entre carneada e matanças de animais de criação em uma comunidade aborígene dos Andes argentinos, observando a necessidade de o animal "morrer bem" como fenômeno imbricado no procedimento de se tirar para fora dos corpos dos animais carneados a sorte que compartilham com o pastor. No campo de Pazzarelli também os animais não podem sentir dor ao morrer. 
como passageiras, encerradas na boleia do caminhão, seus corpos operam uma grande virada no sentido de seu confinamento, de seu "encolhimento". Isso se dá menos pelo transporte em si do que pelas variações nos motivos pelos quais elas viajam.

Quando são encomendadas por alguma casa de religião podem ser carregadas e entregues no mesmo dia, o que não acarreta grandes danos para seus corpos. O problema é quando Teodoro está precisando de dinheiro e liga para Alfredo para oferecer cabritas sem que este tenha um destino imediato para elas que não o galpão e o pátio na cidade. A questão crítica é a conversão em mercadoria, em moeda de troca. A sedentarização imposta pela condição de "estoque" com que Teodoro e o caminhoneiro lidam com os animais. Entre Palmas e os terreiros elas devem ficar o menor intervalo de tempo possível com o mercador, para que seus corpos não se deteriorem. Entre estar na casa de religião e ser abatido, o intervalo também deve ser mínimo, para que seus corpos não se deteriorem ou deteriorem outros corpos.

Aquilo que se diz das cabritas no quilombo, de que sua docilidade e domesticidade dependem do contato cotidiano com os humanos, se inverte na cidade. A imposição de um ambiente "doméstico", sob o olhar vigilante dos humanos, desenha a "selvageria" de outra forma, agressiva e frágil. No quilombo, tornar-se selvagem era sumir, não voltar, por falta de contato com os humanos. $\mathrm{Na}$ cidade, os bodes, principalmente, dão fama aos caprinos de "bichos brabos" ou melhor, embrabecidos. Se no quilombo eles eram tirados dos rebanhos para não copularem com as fêmeas, na cidade não há esta opção. Tanto para Alfredo quanto para Pai Humberto, os bodes entram em cio quando colocados junto com as cabras e ficam agressivos porque são impedidos de copular.

Os corpos das cabritas, dos cabritos, dos bodes, encarnam pelas feridas a racialização como acontecimento. As feridas nas patas são as mais comuns, as frieiras de não andarem ou de andarem sobre o mesmo chão. Mas qualquer ferida ou sangramento é repudiado pelos orixás. O animal a ser abatido para os orixás deve ter tido uma vida saudável, uma vida boa, não pode ter sido maltratado, deve estar bonito e bem alimentado. Segundo Gilmar de Ogum Avagã, o animal não pode ter nenhuma mácula no corpo. Para Gilmar, mácula é qualquer ferimento que sangre. $\mathrm{O}$ sangue escorrendo abre precedentes para que outros seres (espíritos, eguns) já estejam "comendo naquele corpo". Gilmar compara este sangue ao sangue de uma mulher menstruada, que também deve ser afastada de todo e qualquer objeto ou lugar de axé. ${ }^{22}$

Quando Leomar me diz que "o mato deixa a gente todo arranhado", pede que se observem os braços de Ana Luísa, porque ela tem a pele mais clara, e veja os arranhões que trazem dos espinhos de São João, por ela ter que se

22 Sobre o ritual do "chão" como gestação e a ideia de sangue menstrual como fertilidade e signo da alteridade que se alimenta no mesmo, ver Anjos (2001). 
embrenhar no mato com as cabritas. Isso reporta à metáfora que Frantz Fanon (2008) faz da pele negra como "hemorragia que coagula sangue negro sobre todo o corpo".

Assim, quando Gilmar do Ogum diz que um corpo maculado é um corpo com sangue à mostra, pensa-se que quando se oferta um animal "imaculado" a um orixá, o desejo primeiro é de que na vida não se tenha um corpo ferido, um corpo com dor - o que oferecemos aos nossos orixás é o que queremos para nós. Poder-se-ia dizer que qualquer pessoa, negra ou não, deseja não ter dor. Mas o desejo de quem oferta axorô para um orixá que mora no seu corpo, vem de corpos marcados pelos rastros históricos da escravidão - mesmo que o filho-de-santo seja branco, seu orixá é negro e este habita, compõe, o corpo daquele. Novamente, aquilo que Paul Gilroy descreve como "a condição do ser em estado de dor", que seria um estado correlato à presença da morte derivada da escravidão, a qual não existe separada da impressionante criatividade negra em construir relações de persistência da vida apesar da violência que ronda. Os orixás, o axé, são essa possibilidade de criação de vida desde potências de morte. O corpo do animal sem mácula seria a possibilidade de um corpo negro sem mácula, sem feridas? Talvez a atualização de um.

Anjos (2001), focando na condição de "nascimento" das obrigações do batuque, afirma que o ritual de iniciação é uma forma de marcar a passagem da cultura pelo corpo, como destino. Sendo o "chão" vivido como gestação de uma nova pessoa e o "corte" como o parto do orixá, pode-se pensar nesses rituais como de recomposição dos corpos negros, cujo esquema corporal, segundo Fanon (2008), desmoronara para dar lugar a um esquema epidérmico racial.

A lógica das "trocas de saúde" - quando um órgão animal (um rim, por exemplo) é oferecido aos orixás para que o mesmo órgão humano (um rim) seja curado. São lógicas de criação de corpos que comportam o diverso. Opostas a dos frigoríficos, onde as pessoas se cortam ao passo que cortam os corpos dos bichos e já não sabem qual sangue é de quem. Diferente da lógica dos campos de extermínio do holocausto, lógica de dessensibilização da morte, lógica do extermínio da juventude negra brasileira, lógica dos linchamentos de jovens negros, de "punições exemplares”. É contra essa maquinação da destruição do outro que opera a lógica do sacrifício nas religióes de matriz africana, como o batuque. Uma lógica que comporta a (e é ocupada pela) diferença, ao invés de exterminá-la.

Segundo o Atlas da Violência 2017, publicação do Instituto de Pesquisa Econômica Aplicada (IPEA) e o pelo Fórum Brasileiro de Segurança Pública, homens, jovens, negros e de baixa escolaridade são as principais vítimas de mortes violentas no país, sendo a população negra a maioria $(78,9 \%)$ dos $10 \%$ dos indivíduos com mais chances de serem vítimas de homicídios. De cada 100 pessoas assassinadas no Brasil, 7 I são negras. Conforme o estudo, "Jovens e 
negros do sexo masculino continuam sendo assassinados todos os anos como se vivessem em situação de guerra" (IPEA/FBSP 2017: 30). A persistência da relação entre o recorte racial e a violência no Brasil pode ser percebida também na comparação entre a mortalidade de não negras (brancas, amarelas e indígenas), que caiu $7,4 \%$ entre 2005 e 2015 , e a das mulheres negras, que subiu para $22 \%$.

\section{ÚLTIMAS CONSIDERAÇÕES}

Embora estejam comunidades de terreiros e comunidades remanescentes de quilombos agrupadas enquanto comunidades tradicionais negras (Almeida 2006; O’Dwyer 2002), por serem territórios de resistência construídos por africanos e seus descendentes a partir da experiência de diáspora forçada propiciada pela expansão colonialista do capitalismo (Anjos 2003; Goldman 2005), pouco se conhece das vidas e materiais que sustentam o coexistir longamente (Ingold 2015) desses coletivos. Em quilombos urbanos, como é o caso do quilombo Brotas, em Campinas, São Paulo (Ormaneze 2008), ou do quilombo do Alpes, em Porto Alegre, terreiros e comunidade quilombola trazem laços de coexistência e engajamento afirmativo já bastante evidenciados. No que diz respeito às comunidades quilombolas rurais, parece haver uma maior dificuldade de localizar referências a respeito de tais relações. ${ }^{23}$

Muitos estudos atribuem tal "distanciamento" à contundente presença de referências religiosas neopentecostais nas comunidades de remanescentes de quilombos (Campos 2012; Abib e Nascimento 2016) e suas políticas de demonização das religiões de matriz africana. Há também pesquisas que se atêm à aproximação das comunidades quilombolas com igrejas protestantes de confissão luterana (Oliveira, Loner e Santos 2008) e católica (Almeida 1989) como limites para sua interação com coletivos negros como os terreiros.

Outras referências (Dalmaso 2012) trazem dados que supõem que muitos quilombolas praticam as religiões de matriz africana, mas não revelam que o fazem por um certo medo do estigma que elas carregam, de "barbarismo" ou "primitivismo", fato que não facilitaria sua luta por inclusão em projetos estatais de desenvolvimento rural pautados por lógicas sanitárias modernas de produção de alimentos, por exemplo.

Há ainda estudos que conseguem encontrar em um mesmo território negro o reconhecimento de sua remanescência quilombola e a presença de praticantes de religiões de matriz africana (Campos 2012; Ramos 2016).

23 Em Rotas e Diálogos de Saberes da Etnobotânica Transatlântica Negro-Africana: Terreiros, Quilombos, Quintais da Grande BH, Gomes (2009) traça uma rota etnobotânica de plantas medicinais, mágicas, comestíveis, comuns a diferentes configurações de comunidades negras da região metropolitana de Belo Horizonte, Minas Gerais. 
A busca, muitas vezes frustrada, pela presença das práticas de religiões de matriz africana na vida das comunidades negras rurais leva a que muitas antropólogas e antropólogos abordem tais domínios como isolados por suas diferenças cosmológicas e identitárias, postura que colabora para a reprodução dos ideais segregacionistas do Estado com relação às populações negras. Isso acontece numa tentativa de se transplantar as estruturas cosmológicas das religiões de matriz africana para os quilombos, como se elas representassem, em suas divindades, rituais e liturgias, emblemas identitários de um "ser ideal" afro-brasileiro, que seriam vivenciados da mesma forma em qualquer comunidade negra brasileira, não fossem interceptadas pela presença universalista e discriminatória das igrejas neopentecostais e outras religiões cristãs. Assim, esbarra-se na tendência a manter, epistemológica e metodologicamente, a religiosidade branca e suas matrizes culturais como majoritárias, não atentando para as trilhas que se desenvolvem em paralelo, por dentro dos matos, no passo das cabras, por exemplo, no zunido das colmeias de abelhas. É nessas trilhas multiespecíficas, nesses caminhos, que terreiros e comunidades negras rurais vivenciam cosmoecologias comuns.

Neste artigo, pretendeu-se adotar tal atitude epistemológica, com o intuito de não atribuir mais potência epistêmica ao caráter totalizador e racista do Estado brasileiro (e este em relação promíscua com algumas religiosidades neopentecostais) do que à criatividade das comunidades negras em questão em criar e subverter suas próprias fronteiras (Anjos 2017; Goldman 2015a).

Cabras, seres humanos - quilombolas e batuqueiros - e orixás "comendo juntos" não param de criar laços de reciprocidade pragmática (Despret 2016). Reciprocidades cosmoecológicas eclodidas de modos inventivos de viver (Barbosa Neto 2012), zonas de passagem do devir-negro comum quilombola-batuqueiro-cabra. Trilhas de sangue e mel, que seguimos não em busca de zonas de comunicação ou de fusão, unificação das vidas, mas de atenção aos acontecimentos que destacam a diferença e a multiplicidade nos corpos-lugares negros implicados nas peregrinações aqui experimentadas. 


\section{BIBLIOGRAFIA}

ABIB, Pedro, e Solange A. do NASCIMENTO, 2016, "O efeito da cruzada neoevangélica sobre remanescentes de quilombo: questões sobre educação e identidade quilombola", Horizontes, 1 (34): 33-44.

ALMEIDA, Alfredo Wagner Berno de, 1989, "Terras de preto, terras de santo e terras de índio: posse comunal e conflito", Humanidades, 15 (IV), 42-48. Brasília: UnB.

ALMEIDA, Alfredo Wagner Berno de, 2006, Terras de Quilombo, Terras Indígenas, "Babaçuais Livre", "Castanhais do Povo", Faxinais e Fundos de Pasto: Terras Tradicionalmente Ocupadas. Manaus: PPGSCA-UFAM.

ANJOS, José Carlos G., 2001, "O corpo nos rituais de iniciação do batuque”, in Ondina Fachel Leal (org.), Corpo e Significado, 137-151. Porto Alegre: Ed. UFRGS.

ANJOS, José Carlos G. dos, 2003, "Raça e pobreza rural no Brasil Meridional: a comunidade de São Miguel dos Pretos - um estudo de caso”, Teoria e Pesquisa, 42-43, 199-220.

ANJOS, José Carlos G. dos, 2006, No Território da Linha Cruzada: a Cosmopolítica Afro-Brasileira. Porto Alegre: UFRGS/Fundação Cultural Palmares.

ANJOS, José Carlos G. dos, 2017, “Comentários à mesa redonda 'mestiçagens e (contra) mestiçagens ameríndias e afro-americanas'”, R@U Revista de Antropologia da UFSCar, 9 (2): 213-217.

BARbOSA NETO, Edgar R., 2012, A Máquina do Mundo: Variações sobre o Politeísmo em Coletivos Afro-Brasileiros. Rio de Janeiro: Museu Nacional da UFRJ, programa de pós-graduação e Antropologia Social, tese de doutorado.

BASTIDE, Roger, 1971 , As Religiões Africanas no Brasil. São Paulo: Pioneira.

BASTIDE, Roger, 1973, Estudos Afro-Brasileiros. São Paulo: Perspectiva.

BASTIDE, Roger, 2001, O Candomblé da Bahia (Rito Nagô). São Paulo: Companhia das Letras.

BUENO, Winnie de C., 2015, Aspectos Sócio-Jurídicos sobre Intolerância Religiosa, Laicidade do Estado e Direito ao Culto Frente às Tradições de Matriz Africana. Pelotas: Universidade Federal de Pelotas, monografia apresentada ao curso de bacharelado em Direito.

CAMPOS, Juliana M.S., 2012, "Religião no quilombo: relações entre candomblecistas e evangélicos em Mangueiras (MG)”, prêmio Lévi-Strauss (modalidade B - artigo). Brasília: ABA - Associação Brasileira de Antropologia.

CORRÊA, Norton, 2006, O Batuque do Rio Grande do Sul: Antropologia de Uma Religião Afro-rio-grandense. Porto Alegre, BR: Ed. UFRGS.

DALMASO, Flávia, 2012, "Relatório antropológico da comunidade de machadinha/RJ", em Eliane Cantarino O’Dwyer (org.), O Fazer Antropológico e o Reconhecimento de Direitos Constitucionais: o Caso das Terras de Quilombo no Estado do Rio de Janeiro. Rio de Janeiro: e-papers.

DESCOLA, Philippe, 2005, Par de-là nature et culture. Paris: Gallimard.

DESPRET, Vinciane, 2007, Bêtes et hommes. Paris: Gallimard.

DESPRET, Vinciane, 2016, "O que diriam os animais se...?", tradução de Cícero de Oliveira, Caderno de Leitura, 45. Belo Horizonte: Chão da Feira.

DIGARD, Jean-Pierre, 1999, Les Français et leurs animaux. Paris: Fayard.

FANON, Frantz, 2008, Pele Negra, Máscaras Brancas. Salvador: Ed. UFBra.

GEHLEN, Ivaldo, e Iosvaldyr BITTENCOURT JR., 2011 1, Relatório Sócio, Histórico e Antropológico da Comunidade Quilombola de Palmas - Bagé/RS. Porto Alegre: INCRA/UFRGS. 
GOLDMAN, Marcio, 2005, "Formas do saber e modos do ser: observações sobre multiplicidade e ontologia no candomblé”, Religião e Sociedade, 25 (2): 102-120.

GOLDMAN, Marcio, 2015a, “'Quinhentos anos de contato': por uma teoria etnográfica da (contra)mestiçagem", Mana, 21 (3): 641-659.

GOLDMAN, Marcio, 201 5b, Diez Gritos sobre la Campaña contra las Religiones de Matriz Africana. Disponível em < https://www.academia.edu/30649875/> (última consulta em junho de 2021).

GOMES, Ângela Maria da Silva, 2009, Rotas e Diálogos de Saberes da Etnobotânica Transatlântica Negro-Africana: Terreiros, Quilombos, Quintais da Grande BH. Belo Horizonte: UFMG, programa de pós-graduação em Geografia, tese de doutorado.

HARAWAY, Donna, 2008, When Species Meet. Minneapolis: University of Minnesota Press.

INCRA; UfRGS, 2007, Relatório Sócio, Histórico e Antropológico da Comunidade Quilombola de Palmas. Bagé, RS: INCRA.

INGOLD, Tim, 2002, The Perceptions of the Environment: Essays on Livelihood, Dwelling and Skill. Londres: Routledge.

INGOLD, Tim, 2014, “That's enough about ethnography!”, Hau: Journal of Ethnographic Theory, 4 (1): 383-395.

INGOLD, Tim, 2015, Estar Vivo: Ensaios sobre Movimento, Conhecimento e Descrição. Petrópolis: Vozes.

IPEA/FBSP, 2017, Atlas da Violência 2017. Disponível em < https://www.ipea.gov.br/portal/i mages/170609_atlas_da_violencia_2017.pdf > (última consulta em junho de 2021). Rio de Janeiro.

KIRKSEY, Eben, e Stefan HELMREICH, 2010, "The emergence of multispecies ethnography”, Cultural Anthropology, 25 (4): 545-576.

KOSBY, Marília F., 201 1, Os Baobás do Fim do Mundo: Trechos Líricos de Uma Etnografia com Religiões de Matriz Africana no Sul do Rio Grande do Sul. Vera Cruz: Novitas.

KOSBY, Marília F., 2015, Nós Cultuamos Todas as Doçuras: as Religiões de Matriz Africana e a Tradição Doceira de Pelotas. Porto Alegre: Escola de Poesia.

KOSBY, Marília F., 2017, Alma-Caroço: Peregrinações com Cabras Negras pelo Extremo Sul do Brasil. Porto Alegre: UFGRS, programa de pós-graduação em Antropologia Social, tese de doutorado.

KOSBY, Marília F., Daniel V. LIMA, e Flávia S. RIETH, 2017, "Centauros de motocicleta: o cavalo como testemunha do 'processo domesticatório' do gaúcho”, Horizontes Antropológicos, 23 (48): 197-223.

MAESTRI, Mário, 2006 [1984], O Escravo no Rio Grande do Sul. Porto Alegre: UFRGS.

MAESTRI, Mário (org.), 2008, O Negro e o Gaúcho: Estâncias e Fazendas no Rio Grande do Sul, Uruguai e Brasil. Passo Fundo: UPF.

MARCUS, George W., 2001, "Etnografía en/del sistema mundo: el surgimiento de la etnografía multilocal”, Alteridades, 11 (22): 111 -127.

O'DWYER, Eliane Cantarino (org.), 2002, “Os quilombos e a prática profissional dos antropólogos”, in Eliane Cantarino O’Dwyer (org.), Quilombos: Identidade Étnica e Territorialidade. Rio de Janeiro: FGV.

OLIVEIRA, Wilson José F. (org.), Beatriz A. LONER, e Nara Nilcéia S. SANTOS, 2008, “De 'homens de cor' a 'quilombolas': desigualdades étnico-raciais, processos de mediação e atribuições identitárias na constituição da comunidade de Manoel do Rego - Canguçu/ RS”, in INCRA/RS, Relatório Sócio-Antropológico-Histórico e Geográfico. Porto Alegre: INCRA. 
ORMANEZE, Fabiano, 2008, Quilombo Urbano. Consultado em < http://www.palmares.gov.br /archives/3129> (última consulta em fevereiro de 2019, já não disponível).

ORO, Ari P., 2005, "O sacrifício de animais nas religiões afro-brasileiras: análise de uma polêmica recente no Rio Grande do Sul”, Religião e Sociedade, 25: 11-31.

ORO, Ari. P., e Daniel F. BEM, 2008, "A discriminação contra as religiões afro-brasileiras: ontem e hoje", Ciências e Letras, 44: 301-318.

OSÓRIO, Helen, 2005, "Campeiros e domadores: escravos da pecuária sulista, séc. XVIII", Anais Eletrônicos do II Encontro Escravidão e Liberdade no Brasil Meridional. Florianópolis: Ed. UFSC (CD-ROM).

PALERMO, Eduardo, 2013, Tierra Esclavizada: El Norte Uruguayo en la Primera Mitad del Siglo 19. Montevideo: TierrAdentro.

PAZZARELLI, Francisco, 2017, "A sorte da carne: topologia animal nos Andes meridionais", Horizontes Antropológicos, 23 (48): 129-149.

RAMOS, João Daniel D., 2016, "A (cosmo)lógica das relações humano-animais nas religiões afro-brasileiras", Revista Iluminuras, 17 (42): 129-149.

SCHLEE, Aldyr G., 2014, "Linguagem de fronteira", Vox, 7: 22-27.

VECHIA, Agostinho M. dalla, 1994, Vozes do Silêncio: Depoimentos de Descendentes de Escravos no Meridião Gaúcho. Pelotas: Editora da UFPel. 